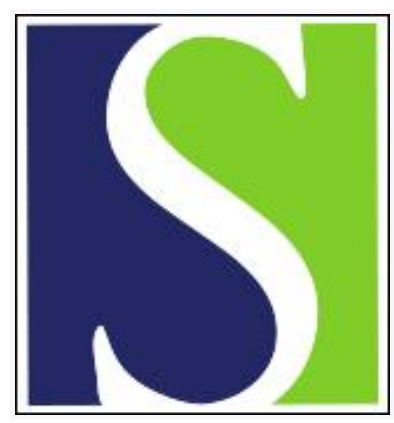

Scand J Work Environ Health 1999;25(3):285-290

https://doi.org/10.5271/sjweh.436

Issue date: Jun 1999

Dental workplace exposure and effect on fertility

by Dahl JE, Sundby J, Hensten-Pettersen A, Jacobsen N

The following articles refer to this text: 2011;37(6):539-546;

2012;38(6):546-552

Key terms: dental amalgam; dentistry; disinfectant; fecundability; fertility; mercury; occupational exposure; time to pregnancy

This article in PubMed: www.ncbi.nlm.nih.gov/pubmed/10450781

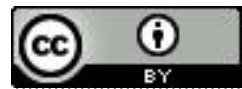




\title{
Dental workplace exposure and effect on fertility
}

\author{
by Jon E Dahl, DDS, ${ }^{1}$ Johanne Sundby, MD, ${ }^{2}$ Arne Hensten-Pettersen, DDS, ${ }^{1}$ Nils Jacobsen, DDS ${ }^{3}$
}

\author{
Dahl JE, Sundby J, Hensten-Pettersen A, Jacobsen N. Dental workplace exposure and effect on fertility. Scand J \\ Work Environ Health 1999;25(3):285-290.
}

\begin{abstract}
Objectives This study assessed occupational exposure in dental surgeries on the basis of the reported use of dental materials and techniques and applied waiting-time-to-pregnancy methodology to study fertility in relation to the occupational exposure.

Methods Data were collected retrospectively using a self-administered postal questionnaire addressing the occupational and reproductive history of the participants. The study groups consisted of 558 female dental surgeons and 450 high school teachers that had given birth in Norway to at least 1 living child. The present study comprised data from a total of 1408 pregnancies. The effects of practicing dentistry and of the given workplace exposure on fertility were analyzed with the discrete proportional hazard regression method.

Results Most of the female dental surgeons were using amalgam for fillings during the period they tried to conceive, and $1 / 3$ placed more than 50 fillings a week. Tooth-colored fillings were in limited use. Prior to $75 \%$ of the pregnancies, the dental surgeons reported handling chloroform-based root canal sealers. Forty percent of the dental surgeons were daily exposed to disinfectants containing ethanol and benzene. No difference was found in fertility between the dental surgeons and the high school teachers. Exposure to mercury, chloroform, and benzene was not associated with decreased fertility, except for a possible effect of mercury in the last pregnancy of multiparous dental surgeons.
\end{abstract}

Conclusions Occupational exposures had no clear adverse effects on fertility among the female dental surgeons studied.

Key terms dental amalgam, dentistry, disinfectants, fertility, fecundability, mercury, occupational exposure, time to pregnancy.

The operations involved in running a dental surgery, such as the handling of unset materials and the use of chemical disinfectants, imply possible occupational hazards. Even if each exposure is usually of short duration, the dental personnel are sometimes exposed repeatedly and to a variety of different chemicals during the workday.

Studies on occupational exposure and the reproduction of female dental personnel have mainly addressed the risk of spontaneous abortion and congenital malformations. In cases of exposure assessment, mercury from dental amalgam has been the only specific toxicant evaluated. Increased risk for miscarriages among dental surgeons has been indicated (1), but not confirmed in later studies $(2-4)$. A report claiming a higher incidence of reproductive failure among women working in dental surgeries (5) has been criticized for methodological shortcomings $(6,7)$. Several investigators have independently concluded that dental personnel do not have an increased risk of giving birth to children with congenital abnormalities $(1,3,4)$.

Miscarriages and congenital malformations may be end points not sensitive enough to identify reproductive hazards. The determination of fecundability, defined as the probability of becoming pregnant in each menstruation cycle, has been suggested as a better approach (8). This method has been used extensively $(8-20)$ and recently validated $(21,22)$. Rowland et al $(10)$ found that working with dental amalgam was not associated with reduced fecundability among female dental assistants. A more-detailed analysis from the same study revealed a

1 NIOM - Scandinavian Institute of Dental Materials, Haslum, Norway.

2 National Institute of Public Health, Oslo, Norway.

3 Dental Faculty, University of Oslo, Oslo, Norway.

Reprint requests to: Dr Jon E Dahl, NIOM - Scandinavian Institute of Dental Materials, PO Box 70, N-1305 Haslum, Norway. [E-mail: jon.dahl@niom.no] 
subgroup with reduced fertility characterized by poor mercury hygiene and high mercury exposure (11).

The aims of the present work were to assess occupational exposure in dental surgeries on the basis of the reported use of dental materials and techniques and to apply waiting-time-to-pregnancy methodology to study fertility in relation to occupational exposure

\section{Subjects and methods}

\section{Study design}

The data were collected retrospectively using a self-administered postal questionnaire. The reproductive history was based on questions developed from draft guidelines of a concerted action program of the European Union called the European Studies on Infertility and Subfecundity (12). The occupational exposure was addressed by a thorough examination of the work performed with specific emphasis on restorative materials and chemicals. Three pregnancies, the first 2 and the last, were included if possible. The study was approved by the National Committee for Research Ethics and the Data Inspectorate. Data were collected during the year 1991.

\section{Participation and inclusion criteria}

The questionnaire was sent to all female dental surgeons registered in the Norwegian Dental Association $(\mathrm{N}=1320)$, and also to a random sample of female high schools teachers $(\mathrm{N}=1084)$, recruited from the register of the Norwegian Educational Association. The effective response rates after 2 reminders were $65 \%$ for the dental surgeons and $70 \%$ for the high school teachers (12). The enrollment criteria of our study were (i) employed as a dental surgeon or high school teacher at the time the couple tried to conceive and (ii) the pregnancy resulted in the birth of a living child. Women who became pregnant in spite of the use of contraception (229 pregnancies) and high school teachers exposed to chemicals (32 pregnancies) were excluded. Our study comprised data from a total of 1408 pregnancies of 1008 women (834 pregnancies of 558 dental surgeons and 574 pregnancies of 450 high school teachers).

\section{Outcome variable}

Fertility was measured by time to pregnancy defined as months of unprotected intercourse required to become pregnant (8). This is an acceptable approximation of the number of cycles needed, provided that the definition is used consistently (23).

\section{Exposure assessment}

The reported number of dental amalgam fillings placed per week served as an approximation of the mercury exposure, and correspondingly, the number of root fillings with chloroform-based root canal sealing material indicated the exposure to chloroform. Radiation exposure was evaluated from the ability of the operator, in their own judgment, to be sufficiently protected during the taking of radiographs. In Norway, benzene $(0.25 \%$,volume per volume) was added to ethanol used for disinfecting purposes until 1985, and, currently, isopropyl alcohol is used to prevent misuse. The frequency of being exposed to vapors from ethanol-based and other chemical disinfectants (aldehydes, chlorinated products and phenols) was reported as never, occasionally, and every day. The occupational exposure of the high school teachers was assessed by open questions regarding type of chemical and frequency of exposure. The respondents reported their exposure emphasizing the 6 months prior to pregnancy.

\section{Analytical approach}

The time-to-pregnancy distribution was determined by a survival analysis (LIFETEST procedure, SAS/STATß). The effects of practicing dentistry and occupational exposure on fertility was analyzed with the discrete proportional hazard regression method (PHREG procedure, SAS/STAT®) producing fecundability ratios. The fecundability ratio was defined as the ratio of the per-cycle conception rate for the exposed in comparison with the reference value. The effects of practicing dentistry and of placing dental amalgam were analyzed separately for each parity. For the other analysis, data for all pregnancies were compiled to increase the sample size. The latter was justified because earlier analysis of the data disclosed no major differences in the time-to-pregnancy distribution between any of the 3 possible pregnancies investigated (12).

\section{Results}

\section{Exposure assessment}

Most dental surgeons placed amalgam fillings at the time they tried to conceive. One-third placed more than 50 fillings a week and $1 / 3$ placed $21-50$ fillings a week (table 1 ). There has been a reduction in the number of amalgam fillings placed over the last 4 decades (table 2). Tooth-colored fillings were selected less frequently than dental amalgam and not used at all in nearly $60 \%$ of the cases (table 1). In approximately $75 \%$ of the pregnancies, the women reported use of chloroform-based endodontic sealing materials (table 1). Ethanol-based disinfectants were in common use. Forty percent of the dental surgeons reported daily exposure to ethanol containing benzene, and $11 \%$ had daily exposure to a combination of ethanol and isopropyl alcohol (table 1). 
Possible exposure to radiation during the time prior to pregnancy was reported in less than $5 \%$ of the cases (table 1).

\section{Fertility}

In about $50 \%$ of the studied pregnancies, fertilization occurred during the first month of unprotected intercourse, and in approximately $10 \%$ of the cases the couple used more than 1 year to achieve the wanted pregnancy. The results of the regression analysis of possible risk activity are given in tables 3 and 4 . The fecundability ratio was slightly reduced for the last pregnancy of the dental surgeons with more than 2 children, but no effect was observed for the other parities (table 3 ). The placing of dental amalgam was not associated with a reduced fecundability ratio for any of the subgroups analyzed (parity, age, time periods, and levels of exposure) and by internal comparisons among the dental surgeons (table 3). Other defined dental work where exposure to toxicants was possible did not influence the fecundability ratio (table 4 ).

\section{Discussion}

Frequent use of dental materials and disinfecting agents indicated that the female dental surgeons had the possibility of being exposed to hazardous chemicals such as mercury during the period they tried to conceive. A correlation between the placement of amalgam and the concentration of mercury in the urine of dental staff has been found earlier $(24,25)$. Data from the United States have indicated that dental surgeons placing more than 50 amalgam fillings a week have an average urinary mercury concentration of approximately $20 \mu \mathrm{g} / 1$ (24). We found that, before $1980,50-70 \%$ of the conceptions occurred in time periods when the dental surgeon placed more than 50 amalgam fillings a week and was likely to have such a urinary mercury concentration. The average mercury concentration in the urine of dental personnel in Norway in the $1970 \mathrm{~s}$ was $10-20 \mu \mathrm{g} / \mathrm{l}(25)$; these data support our estimates.

The analysis showed that the placement of dental amalgam had no effect on fertility among the dental surgeons. The results were clear and consistent also for the subgroup placing more than 100 dental amalgam fillings a week, and also for periods in which the exposure to mercury was likely to be highest. Separate analysis for the age group of $\geq 30$ years, for which a lower fertility rate was observed (12), revealed no difference. Practicing dentistry and placing dental amalgam might have a small negative effect on fecundability at the time of last pregnancy of women having 3 or more children. This
Table 1. Occupational exposure of female dental surgeons at the time the couple tried to conceive. Exposures to constituents of filling materials and to vapor from disinfectants were based on the self-assessed frequency of use, and to radiation on the selfassessed possibility of being protected during the taking of radiographs. ( $\mathrm{N}=$ number of respondents)

\begin{tabular}{|c|c|c|}
\hline Exposure agent & N & $\%$ \\
\hline \multicolumn{3}{|c|}{ Mercury containing dental amalgam ( $\mathrm{N}=799$ ) } \\
\hline $\begin{array}{l}0 \text { number of fillings per week } \\
1-20 \text { number of fillings per week } \\
21-50 \text { number of fillings per week } \\
51-100 \text { number of fillings per week } \\
>100 \text { number of fillings per week }\end{array}$ & $\begin{array}{r}46 \\
195 \\
278 \\
213 \\
67\end{array}$ & $\begin{array}{r}5.8 \\
24.4 \\
34.8 \\
26.7 \\
8.4\end{array}$ \\
\hline \multicolumn{3}{|l|}{ Tooth colored restorations ( $N=799$ ) } \\
\hline $\begin{array}{l}0 \text { number of fillings per week } \\
1-20 \text { number of fillings per week } \\
21-50 \text { number of fillings per week } \\
51-100 \text { number of fillings per week } \\
>100 \text { number of fillings per week }\end{array}$ & $\begin{array}{r}456 \\
233 \\
91 \\
15 \\
4\end{array}$ & $\begin{array}{r}57.1 \\
29.2 \\
11.4 \\
1.9 \\
0.5\end{array}$ \\
\hline \multicolumn{3}{|c|}{ Chloroform-containing root canal sealer $(\mathrm{N}=792)$} \\
\hline $\begin{array}{l}0 \text { number of fillings per week } \\
<1 \text { number of fillings per week } \\
1-2 \text { number of fillings per week } \\
3-5 \text { number of fillings per week } \\
>5 \text { number of fillings per week }\end{array}$ & $\begin{array}{r}211 \\
405 \\
119 \\
53 \\
4\end{array}$ & $\begin{array}{r}26.7 \\
51.0 \\
15.0 \\
6.7 \\
0.5\end{array}$ \\
\hline \multicolumn{3}{|l|}{ Methylated ethanol $(\mathrm{N}=772)$} \\
\hline $\begin{array}{l}\text { Never exposed } \\
\text { Exposure with benzene }\end{array}$ & \multicolumn{2}{|c|}{ Exposure with benzene } \\
\hline $\begin{array}{l}\text { Exposed occasionally } \\
\text { Exposed daily }\end{array}$ & $\begin{array}{l}192 \\
310\end{array}$ & $\begin{array}{l}24.9 \\
40.2\end{array}$ \\
\hline \multicolumn{3}{|l|}{ Exposure with isopropyl alcohol } \\
\hline $\begin{array}{l}\text { Exposed occasionally } \\
\text { Exposed daily }\end{array}$ & $\begin{array}{l}59 \\
84\end{array}$ & $\begin{array}{r}7.6 \\
10.9\end{array}$ \\
\hline \multicolumn{3}{|l|}{ Chlorhexidine and ethanol $(\mathrm{N}=624)$} \\
\hline $\begin{array}{l}\text { Never exposed } \\
\text { Exposed occasionally } \\
\text { Exposed daily }\end{array}$ & $\begin{array}{r}453 \\
90 \\
81\end{array}$ & $\begin{array}{l}72.6 \\
14.4 \\
13.0\end{array}$ \\
\hline \multicolumn{3}{|l|}{ Aldehydes $(\mathrm{N}=634)$} \\
\hline $\begin{array}{l}\text { Never exposed } \\
\text { Exposed occasionally } \\
\text { Exposed daily }\end{array}$ & $\begin{array}{r}503 \\
97 \\
34\end{array}$ & $\begin{array}{r}79.3 \\
15.3 \\
5.4\end{array}$ \\
\hline \multicolumn{3}{|l|}{ Phenols $(\mathrm{N}=662)$} \\
\hline $\begin{array}{l}\text { Never exposed } \\
\text { Exposed occasionally } \\
\text { Exposed daily }\end{array}$ & $\begin{array}{r}506 \\
101 \\
15\end{array}$ & $\begin{array}{r}81.4 \\
16.2 \\
2.4\end{array}$ \\
\hline \multicolumn{3}{|l|}{ Chlorides $(\mathrm{N}=626)$} \\
\hline $\begin{array}{l}\text { Never exposed } \\
\text { Exposed occasionally } \\
\text { Exposed daily }\end{array}$ & $\begin{array}{r}455 \\
149 \\
22\end{array}$ & $\begin{array}{r}72.7 \\
23.1 \\
3.5\end{array}$ \\
\hline \multicolumn{3}{|l|}{$\mathrm{X}$-ray radiation $(\mathrm{N}=830)$} \\
\hline $\begin{array}{l}\text { Not exposed } \\
\text { Exposed }\end{array}$ & $\begin{array}{r}793 \\
37\end{array}$ & $\begin{array}{r}95.5 \\
4.5\end{array}$ \\
\hline
\end{tabular}

Table 2. Distribution of placed amalgam fillings according to the time prior to pregnancy in relation to the decade when pregnancy occurred. ( $N=$ number of respondents)

\begin{tabular}{lrccc}
\hline $\begin{array}{l}\text { Fillings } \\
\text { per week }\end{array}$ & $\begin{array}{c}1 \mathrm{~N}=61) \\
(\%)\end{array}$ & $\begin{array}{c}1961-1970 \\
(\mathrm{~N}=132) \\
(\%)\end{array}$ & $\begin{array}{c}1971-1980 \\
(\mathrm{~N}=214) \\
(\%)\end{array}$ & $\begin{array}{c}1981-1990 \\
(\mathrm{~N}=378) \\
(\%)\end{array}$ \\
\hline None & 1.6 & 2.2 & 2.3 & 9.8 \\
$1-20$ & 1.6 & 4.6 & 11.2 & 42.6 \\
$21-50$ & 24.6 & 37.1 & 36.6 & 35.2 \\
$51-100$ & 55.7 & 35.6 & 39.2 & 11.4 \\
$>100$ & 16.4 & 20.5 & 10.8 & 1.1 \\
\hline
\end{tabular}


Table 3. Estimated fecundability ratios for subgroups of female dental surgeons. Comparable reference groups are given in the table. The values have been adjusted for age, smoking habits, and medical history indicating reduced fertility for the respondent and spouse. ( $\mathrm{N}=$ number of pregnancies, $95 \% \mathrm{Cl}=95 \%$ confidence interval)

\begin{tabular}{|c|c|c|c|}
\hline Risk activity & $\begin{array}{l}\text { Fecundability } \\
\text { ratio }\end{array}$ & $95 \% \mathrm{Cl}$ & Reference group \\
\hline \multicolumn{3}{|l|}{ Practicing dentistry } & High school teachers \\
\hline First pregnancy $(\mathrm{N}=491)$ & 1.00 & $0.99-1.01$ & First pregnancy $(\mathrm{N}=379)$ \\
\hline Second pregnancy $(\mathrm{N}=266$ ) & 1.00 & $0.99-1.02$ & Second pregnancy $(\mathrm{N}=175)$ \\
\hline Last pregnancy $(\mathrm{N}=77)$ & 0.97 & $0.93-1.01$ & Last pregnancy $(\mathrm{N}=20)$ \\
\hline \multicolumn{3}{|l|}{ Practicing dentistry for $\geq 10$ years } & High school teachers for more than 10 years \\
\hline First pregnancy $(\mathrm{N}=27)$ & 1.03 & $1.00-1.07$ & First pregnancy $(\mathrm{N}=25)$ \\
\hline Second pregnancy $(\mathrm{N}=50)$ & 1.00 & $0.97-1.03$ & Second pregnancy $(\mathrm{N}=29)$ \\
\hline Last pregnancy $(\mathrm{N}=34)$ & 0.96 & $0.92-1.00$ & Last pregnancy $(\mathrm{N}=12)$ \\
\hline \multicolumn{3}{|l|}{ Placing dental amalgam } & High school teachers \\
\hline First pregnancy $(\mathbb{N}=413)$ & 1.02 & $0.97-1.07$ & First pregnancy $(\mathrm{N}=379)$ \\
\hline First pregnancy, age $>30$ years $(\mathrm{N}=175)$ & 0.95 & $0.87-1.05$ & First pregnancy, age above 30 years $(\mathrm{N}=160)$ \\
\hline Second pregnancy $(\mathrm{N}=254)$ & 1.01 & $0.93-1.09$ & Second pregnancy $(\mathrm{N}=175)$ \\
\hline Second pregnancy, age $>30$ years $(N=185)$ & 0.98 & $0.90-1.07$ & Second pregnancy, age above 30 years $(N=127)$ \\
\hline Last pregnancy, age $>30$ years $(N=51)$ & 0.83 & $0.67-1.03$ & Last pregnancy, age above 30 years $(\mathrm{N}=20)$ \\
\hline \multicolumn{3}{|l|}{ Placing dental amalgam (all pregnancies) } & High school teachers (all pregnancies) \\
\hline Pregnancy occurring during $1951-1960(\mathrm{~N}=60)$ & 0.97 & $0.83-1.12$ & Pregnancy occurring during years $1951-60(\mathrm{~N}=18)$ \\
\hline Pregnancy occurring during $1961-1970(\mathrm{~N}=129)$ & 1.02 & $0.92-1.12$ & Pregnancy occurring during years $1961-70(\mathrm{~N}=80)$ \\
\hline Pregnancy occurring during $1971-1980(\mathrm{~N}=218)$ & 1.03 & $0.96-1.11$ & Pregnancy occurring during years $1971-80(\mathrm{~N}=187)$ \\
\hline Pregnancy occurring during $1981-1990(\mathrm{~N}=311)$ & 0.98 & $0.90-1.06$ & Pregnancy occurring during years $1981-90(\mathrm{~N}=285)$ \\
\hline \multicolumn{4}{|l|}{ Placing dental amalgam (all pregnancies) } \\
\hline$>51$ dental amalgams/week $(\mathrm{N}=262)$ & 1.00 & $0.96-1.05$ & High school teachers (all pregnancies) $(\mathrm{N}=574)$ \\
\hline$>100$ dental amalgams/week $(N=67)$ & 1.04 & $0.97-1.11$ & $\begin{array}{l}\text { High school teachers (all pregnancies) }(\mathrm{N}=574) \\
\text { Dentists (all pregnancies) placing }\end{array}$ \\
\hline$>51$ dental amaigams/week $(\mathrm{N}=262)$ & 0.96 & $0.81-1.13$ & $<20$ dental amalgams/week $(N=217)$ \\
\hline$>100$ dental amalgams/week $(N=67)$ & 1.13 & $0.86-1.49$ & $<20$ dental amalgams/week $(\mathrm{N}=217)$ \\
\hline
\end{tabular}

Table 4. Estimated fecundability ratios for different occupational activities and exposures of female dental surgeons. The reference group consisted of female high school teachers $(\mathrm{N}=574$ pregnancies). The data from all pregnancies have been pooled and the values have been adjusted for age, smoking habits and medical history indicating reduced fertility for the respondent and spouse. ( $\mathrm{N}=$ number of pregnancies, $95 \% \mathrm{Cl}=95 \%$ confidence interval)

\begin{tabular}{|c|c|c|c|}
\hline Risk activity & N & $\begin{array}{l}\text { Fecunda- } \\
\text { bility ratio }\end{array}$ & $95 \% \mathrm{Cl}$ \\
\hline Placing tooth-colored restorations & 329 & 1.04 & $0.95-1.12$ \\
\hline Placing chloroform based root fillings & 582 & 1.06 & $0.95-1.10$ \\
\hline $\begin{array}{l}\text { Daily exposure to methylated ethanol } \\
\text { with benzene }\end{array}$ & 310 & 1.01 & $0.93-1.09$ \\
\hline $\begin{array}{l}\text { Daily exposure to methylated ethanol } \\
\text { with isopropyl alcohol }\end{array}$ & 84 & 1.06 & $0.80-1.38$ \\
\hline $\begin{array}{l}\text { Daily exposure to chlorhexidine and } \\
\text { ethanol }\end{array}$ & 81 & 0.96 & $0.75-1.20$ \\
\hline Daily exposure to aldehydes & 34 & 1.10 & $0.78-1.54$ \\
\hline Daily exposure to phenols & 15 & 0.89 & $0.52-1.48$ \\
\hline Daily exposure to chlorides & 22 & 1.25 & $0.81-1.89$ \\
\hline $\begin{array}{l}\text { Insufficient protection during the taking } \\
\text { of radiographs }\end{array}$ & 36 & 0.97 & $0.68-1.36$ \\
\hline
\end{tabular}

possibility could be explained by the need for long-term occupational exposure to initiate the effect, but the fact that there was no association between the number of years in practice and reduced fertility for the first and second pregnancies contradicts this explanation. The ac- tual subgroups were small $(\mathrm{N}=12-51)$, and an effect of recall bias, such as intermittent use of birth control, may be more pronounced.

Rowland et al (11) found reduced fertility in a small group $(\mathrm{N}=38)$ of dental assistants who prepared more than 30 amalgam fillings a week and used poor mercury hygiene. Their study was somewhat difficult to interpret, as there was no clear dose-effect relationship. We did not study mercury hygiene in detail, but did not find any difference in fecundability in our analyses of time periods back to 1951, when the number of placed dental amalgams was higher than in later decades and the dental procedures implied a higher possible risk for mercury exposure.

The use of carcinogenic and reproductive toxicants, such as chloroform and benzene $(26-28)$, in the dental surgeries is of concern even though no adverse effect on fertility was observed from any of the chemicals. Chloroform has been reported to exceed the occupational exposure limit during the preparation of root canal sealers (29), but no information was available on benzene exposure. For the other risk activities investigated, there were no indications of reproductive toxic effects.

Retrospectively collected time-to-pregnancy data provide a suitable design for studying occupational-related fertility problems (22). The respondents' ability to recall their time to pregnancy correctly is considered accepta- 
ble, even with recall times of 14 years and more (21). In our study, $75 \%$ of the pregnancies had occurred within 2 decades of the data collection, and therefore the reliability of our study was high even though recall times up to 40 years existed. The analyses were confined to live births, and they excluded pregnancies conceived in spite of the use of birth control to increase the confidence in the data $(21,22)$. The occupational history was restricted to 6 months prior to pregnancy. For the women with a long waiting time to pregnancy, there was a possibility of exposure bias in that exposure had been different earlier (30). Another problem concerning the validity of exposure data obtained by questionnaires is the possibility of underestimating the exposure (31). Since our reference group was not exposed to the agents used by dental surgeons, the underestimating bias had little effect on the results when the 2 cohorts were compared. On the other hand, an exposure recall bias might have affected internal comparisons in the group of dental surgeons.

Two criteria must be fulfilled for the interpretation of no effect in occupational epidemiology (32). The relative risk estimate must be near unity with a close confidence interval, and systematic errors in the assessment of exposure and effect must be avoided. The results from our study comply with the first requirement. We prevented systematic exposure errors from participant assignment to erroneous exposure groups by selecting the reference group from a different occupation. The systematic effect error would be over- or underestimation of the waiting time to pregnancy. However, since the exposed and reference groups were demographically similar (12), a recall bias in only 1 of the groups seemed unlikely.

Thus we conclude that occupational exposure does not have an adverse effect on fertility among female dental surgeons when they are compared with high school teachers. In detail, the frequent use of dental amalgam, disinfectants, and chloroform-based root canal sealers in our study did not reduce fecundability.

\section{Acknowledgments}

The data were skillfully transferred from the questionnaires into the computerized data base by Ms Siri Weidemann, Ms Inger Nordahl, Ms Anne Wesmann, Ms Else Morisbak, and Ms Anette Kullmann, to whom all the authors express their sincere thanks.

\section{References}

1. Nixon GS, Helsby CA, Gordon H, Hytten FE, Renson CE. Pregnancy outcome in female dentists. Br Dent $\mathrm{J}$
1979;146:39-42.

2. Heidam LZ. Spontaneous abortions among dental assistants, factory workers, painters, and gardening workers: a follow up study. J Epidemiol Community Health 1984;38:149-55.

3. Brodsky JB, Cohen EN, Whicher C, Brown Jx BW, Wu ML. Occupational exposure to mercury and pregnancy outcome. J Am Dent Assoc 1985;111:779—80.

4. Ericson A, Källén B. Pregnancy outcome in women working as dentists, dental assistants or dental technicians. Int Arch Occup Environ Health 1989;61:329-33.

5. Sirkorski R, Juszkiewicz T, Paszkowski T, Szprengier-Juszkiewicz T. Women in dental surgeries: reproductive hazards in occupational exposure to metallic mercury. Int Arch Occup Environ Health 1987;59:551-7.

6. Larsson KS. Teratological aspects of dental amalgam. Adv Dent Res 1992;6:114—9.

7. Larsson KS. The dissemination of false data through inadequate citation. J Intern Med 1995;238:445-50.

8. Baird DD, Wilcox AJ, Weinberg CR. Use of time to pregnancy to study environmental exposures. Am J Epidemiol 1986;124:470—80.

9. Schaumburg I, Olsen J. Time to pregnancy among Danish pharmacy assistants. Scand J Work Environ Health 1989;15:222-6.

10. Rowland AS, Baird DD, Weinberg CR, Shore DL, Shy CM, Wilcox AJ. Reduced fertility among women employed as dental assistants exposed to high levels of nitrous oxide. $N$ Engl J Med 1992;327:993-7.

11. Rowland AS, Baird DD, Weinberg CR, Shore DL, Shy CM, Wilcox AJ. The effect of occupational exposure to mercury vapour on fertility of female dental assistants. Occup Environ Health 1994;51:28-34.

12. Sundby J, Dahl JE. Are women in the workplace less fertile than women who are not employed? J Women's Health 1994:3:65-72.

13. Sallmén M, Anttila A, Lindbohm M-L, Kyyrönen P, Taskinen $\mathrm{H}$, Hemminki $\mathrm{K}$. Time to pregnancy among women occupationally exposed to lead. J Occup Environ Med 1995;37:931 4.

14. Sallmén M, Lindbohm M-L, Kyyrönen P, Nykyri E, Anttila A, Taskinen $\mathrm{H}$, et al. Reduced fertility among women exposed to organic solvents. Am J Ind Med 1995;27:699-713.

15. Bisanti L, Olsen J, Basso O, Thonneau P, Karmaus W, The European Study Group on Infertility and Subfecundity. Shift work and subfecundity: a European multicenter study. J Occup Environ Med 1996;38:352-8.

16. Spinelli A, Figà-Talamanca I, Osborn J. Time to pregnancy and occupation in a group of Italian women. Int J Epidemiol 1997;26:601-9.

17. Linn S, Schoenbaum SC, Monson RR, Rosner B, Ryan KJ Delay in conception for former 'pill' users. JAMA 1982;247:629-32.

18. Baird DD, Wilcox AJ. Cigarette smoking associated with delayed conception. JAMA 1985;253:2979-83.

19. Weinberg CR, Wilcox AJ, Baird DD. Reduced fecundability in women with prenatal exposure to cigarette smoking. Am J Epidemiol 1989:129:1072-8.

20. Bolumar F, Olsen J, Boldsen J, The European Study Group on Infertility and Subfecundity. Smoking reduces fecundity: a European multicenter study on infertility and subfecundity. Am J Epidemiol 1996;143:578-87.

21. Joffe M, Villard L, Li Z, Plowman R, Vessey M. A time to pregnancy questionnaire designed for long term recall: validity in Oxford, England. J Epidemiol Community Health 
$1995: 49: 314-9$

22. Joffe M, Asclepios prosject. Time to pregnancy: a measure of reproductive function in either sex. Occup Environ Med 1997;54:289-95.

23. Baird DD, Wilcox AJ. Effects of occupational exposures on the fertility of couples. Occup Med 1986;1:361-74.

24. Naleway C, Sakaguchi R, Mitchell E, Muller T, Ayer WA, Hefferren JJ. Urinary mercury levels in US dentists, 19751983: review of Health Assessment Program. J Am Dent Assoc 1985;111:37-42.

25. Jokstad A. Mercury excretion and occupational exposure of dental personnel. Community Dent Oral Epidemiol 1990;18:143-8.

26. World Health Organization (WHO). Chloroform. Geneva: WHO, 1994. Environmental health criteria, no 163.

27. World Health Organization (WHO). Benzene. Geneva: WHO, 1993. Environmental health criteria, no 150.

28. US Department of Health and Human Services. RTECS Reg- istry of toxic effects of chemicals. Cincinnati $(\mathrm{OH})$ : US Department of Health and Human Services, 1998. NIOSH compact dise $\mathrm{C} 2$ (98-1).

29. Rapport om kjemisk helsefare på tannklinikken [Report on chemical hazard in surgeries of the community dental service]. Troms (Norway): Den offentlige tannhelsetjenesten i Troms, 1989.

30. Weinberg CR, Baird DD, Wilcox AJ. Sources of bias in studies of time to pregnancy. Stat Med 1994;13:671-81.

31. Ahlborg GA Jr. Validity of exposure data obtained by questionnaire: two examples from occupational reproductive studies. Scand J Work Environ Health 1990;16:284-8.

32. Ahlbom A, Axelson O, Støttrup Hansen E, Hogstedt C, Jensen UJ, Olsen J. Interpretation of "negative" studies in occupational epidemiology [review]. Scand J Work Environ Health 1990;16:153-7.

Received for publication: 29 September 1998 